\title{
INTERNATIONALIZATION OF BRAZILIAN MNCS IN CEMENT INDUSTRY: A KNOWLEDGE FLOW APPROACH
}

\author{
Belmiro do Nascimento João \\ Pontifícia Universidade Católica de São Paulo \\ Universidade Católica de Santos \\ Matheus Iwao Oshikiri \\ Pontifícia Universidade Católica de São Paulo
}

\author{
Aldo Brunhara \\ Pontifícia Universidade Católica de São Paulo
}

\begin{abstract}
This paper presents an empirical study of the international operations of Brazilian MNCs in Cement Industry with a dynamic approach using knowledge-based strategies (KBV) through the analysis of the development of three families of intangible assets (individual competence, internal structure, and external structure). The work analyses the processes of transfer and conversion of knowledge from these three asset structures, with the interaction among these nine strategies resulting in a strategy of maximisation of value creation. The study shows that it is indeed possible to apply this KBV model to a company centred on resources and competences (RBV).
\end{abstract}

Keywords

Knowledge-Based View, Knowledge flows, Knowledge strategies.

\section{Resumo}

Este artigo apresenta um estudo empírico das operações internacionais das cimenteiras brasileiras com uma abordagem dinâmica usando estratégias baseadas no conhecimento (KBV) através da analise do desenvolvimento de três famílias de ativos intangíveis (competência individual, estrutura interna e externa). O trabalho analisa o processo de transferência e conversão do conhecimento dessas três estruturas de ativos, com a interação entre essas nove estratégias resultando em uma estratégia de maximização da criação de valor. O estudo mostra

eGesta - Revista Eletrônica de Gestão de Negócios - ISSN 1809-0079

Mestrado em Gestão de Negócios - Universidade Católica de Santos

Facultade de Ciencias Económicas e Empresariais - Universidade de Santiago de Compostela 
que e possível aplicar este modelo de KBV para uma companhia centrada em recursos e competências (RBV).

\section{Palavras-chave}

Visão Baseada no Conhecimento, Fluxos de Conhecimento, Conhecimento e Estratégias. 


\title{
INTERNATIONALIZATION OF BRAZILIAN MNCS IN CEMENT INDUSTRY: A KNOWLEDGE FLOW APPROACH
}

\author{
Belmiro do Nascimento João \\ Pontifícia Universidade Católica de São Paulo \\ Universidade Católica de Santos \\ Matheus Iwao Oshikiri \\ Pontifícia Universidade Católica de São Paulo \\ Aldo Brunhara \\ Pontifícia Universidade Católica de São Paulo
}

\section{Introduction}

Over the last two decades, the resource-based view of the firm has warranted special attention as an alternative to the traditional view based on the product or the view of competitive advantage (PORTER, 1980). In this paper, we present a new vision of strategy as being based on knowledge, taking it as an initial reference for core competences and the traditional resource-based view (RBV). To help in this ultimate aim, an empirical research has been conducted; with the study objects being Camargo Corrêa Group (Camargo Correa Cimentos (CCC) including Loma Negra in Argentina) and Votorantim Group (Votorantim Cimentos (VC) and St. Mary's \& Suwannee in the United States and Canada) only the cement operations of these groups is focused. According FDC-CPII 2008 ranking of Brazilian multinational enterprises (FDC, 2009) Camargo Corrêa Cimentos is top \#1 MNC 
(transnationality index $=0,585^{1}$ ) and Votorantim Cimentos is top \#4 MNC (transnationality index $=0,397^{2}$ ). To fully understand the strategy model to be analysed here, it is essential to have a good understanding of the business model of cement companies, including downstream operations.

As part of this research, an exploratory study was made on the development of knowledge-based view (KBV) at Camargo Correa \& Votorantim Groups and its international operations. The development of assets relating to external structure, individual competences and internal structure was duly highlighted. There was also the identification of transfer and conversion of knowledge between different structures (internal and external) and assets of individual competence, as shown in the construct of Figure 1.

This paper consists of this introduction, the second section we explore theoretical background with a review about core competences, knowledge flows and dynamic approach to knowledge-based strategies, the third section about methodology. The fourth section with a view of the cement industry and the next section is about the cement Brazilian groups analysed, the sixth section about a business model for value creation. The seventh section about development of strategic skills in the three families of intangible assets. In the next section the data analysis for the nine strategies of the theoretical construct and finally the conclusions.

\footnotetext{
${ }^{1}$ The composite index for Camargo Corrêa Cimentos is 0,499 (foreign sales/total sales); 0,664 (permanent assets abroad in the company's productive chain (including investments, even without holding $100 \%$ of the capital)/total company assets and 0,592 (employees abroad/total employees).

2 The composite index for Votorantim Cimentos is 0,370 (foreign sales/total sales); 0,487 (permanent assets abroad in the company's productive chain (including investments, even without holding $100 \%$ of the capital)/total company assets and 0,333 (employees abroad/total employees).
}

eGesta - Revista Eletrônica de Gestão de Negócios - ISSN 1809-0079

Mestrado em Gestão de Negócios - Universidade Católica de Santos

Facultade de Ciencias Económicas e Empresariais - Universidade de Santiago de Compostela 


\title{
2 Theoretical background
}

\subsection{Core Competences and Knowledge Flows}

After the Second World War, the rapid development of MNCs and their FDI caused widespread interest among western scholars. They adopted different research methods and created basic assumptions towards different research objects, and consequently created various $\mathrm{MNC}$ theories. Companies are expected to follow a sequence from low to high commitment modes of operation to enter new markets with successively greater psychic distance.

Those MNCs theories were concentrated on first-movers of European and American MNCs, few studies were focused on the large amount of emerging late-movers of MNCs, especially overseas Latin American MNCs. The background of those theories was the economic and technological environment before the mid-1980s. MNC theories have been based on the previous history, which cannot explain the development of MNCs in emerging markets. As Govindarajan and Gupta (2001, p.137)

\begin{abstract}
Whenever a company extends its presence across borders, it is confronted with diversity. Diversity, however, represents not just a challenge with which the firm must cope but also a critical resource that the firm can use to create value for customers as well as shareholders.... Every such local innovation represents the creation of new knowledge. Although some of new knowledge may be too idiosyncratic to have much value outside the local environment, a good chunk of what starts out as locally created knowledge often has global relevance and value.
\end{abstract}

The authors have other papers about knowledge flows in MNCs as Gupta and Govindarajan (1991) and Gupta and Govindarajan (2000). Others authors as Oetti and Agrawal (2008) in international labour mobility, Adler and Hashai (2007) about the 
modelling of the multinational enterprise, Mudambi and Navarra (2004) in the power in knowledge flow by subsidiaries and rent-seeking within MNCs.

Many IB researchers use a new approach for strategies in emerging markets as London and Hart (2004) argues

established markets becoming satured .... (MNCs) have turnerd increasingly to emerging markets (EMs) in the developing world. .... Recently, however, a number of MNCs have launched new initiatives that explore the untapped market potential at the base of economic pyramid, the largest and fastestgrowing segment of the world's population.

More recently, MNCs from developing countries seems to make the opposite movement exploring mature markets from triad (BCG, 2006, 2007).

Others IB researchers in recent literature highlighted on the differentiated MNC and in particular with its stress on intra-MNC knowledge flows and the characteristics of knowledge as determinants of knowledge transfer within MNCs. The focus of knowledge is in the subsidiaries, the sources of transferable subsidiary knowledge and on the organizational means and conditions that realize knowledge transfer as the relevant determinants as cited in the works of Foss and Pedersen (2002) and Lagerström and Andersson (2003).

Due to the dispersion of knowledge, both within and outside the company, and also the uncertainty of the environment, its acquisition is an important process through which the managers can identify and absorb the relevant knowledge being created. The construction of external collaboration is important to the updating of the knowledge based in companies, either through R\&D partnerships, or through alliances or acquisitions of other companies and processes of internal knowledge acquisition. The transfer of the competences involved in the encoding of knowledge becomes real when the tacit knowledge regarding innovations

eGesta - Revista Eletrônica de Gestão de Negócios - ISSN 1809-0079

Mestrado em Gestão de Negócios - Universidade Católica de Santos

Facultade de Ciencias Económicas e Empresariais - Universidade de Santiago de Compostela 
becomes more explicit, so that it may be easier to communicate and be understood by people (EISENHARDT; SANTOS, 2002).

The concept of competence gained new importance and started to be distinguished as a feature of an organisation. Competence is often seen as a link between knowledge and strategy, like in the case of an organisation's skill in implementation or action together with other organisations. Prahalad and Hamel (1990) include technical and administrative skills that enable the organisation to survive, which they call "core competences".

In the long term, the core competences turn into competitive advantage, through the skill in building unique competences and anticipation of needs. The source of this advantage resides in the ability to consolidate technologies (including management) for the organisation as a whole, and knowledge of competence-based production. These core competences are, in fact, a process of continuous learning within the organisation, especially in relation to how to co-ordinate different production skills, in harmony with technology flow, the organisation of labour and the delivery of value (PRAHALAD; HAMEL, 1990).

\subsection{A Dynamic Approach to Knowledge-Based Strategies}

As Teece (2001,p.125) correctly pointed out "With the liberation and expansion of markets domestically and internationally, the shift to knowledge assets as the basis of competitive advantage has become compelling". The knowledge-based view of the firm $(\mathrm{KBV})$ of the company suggests that the main reason for the existence of a company is the creation and application of knowledge (DEMSETZ, 1991; KOGUT; ZANDER, 1992, 1993; GRANT, 1996; SPENDER, 1996; SPENDER; GRANT, 1996). Bierly and Chakrabarti (1996) 
reach the conclusion that differences in performance between companies are the result of different knowledge bases and different degrees of skill in developing and subdividing knowledge. According to Eisenhardt and Santos (2002), KBV considers knowledge to be the most important strategic resource within a company, and those who propose this view argue that heterogeneous knowledge bases between companies are the main causative factors of sustained competitive advantage and better corporate performance.

Sveiby, Linard and Dvorsky (2002), and Sveiby (2001), based on a Resource-Based View (RBV) (WERNERFELF, 1984; BARNEY, 1991; PETERAF, 1993; COLLIS; MONTGOMERY, 1995; BARNEY; ARIKAN, 2001), use a self-poietic epistemology (a network of processes producing their own components) to guide the preparation of a strategy. People make use of their "capacity for action", so as to create value through the transfer and conversion of knowledge. The value grows every time there is a transfer or conversion of knowledge. Sveiby, Linard and Dvorsky (2002) and Sveiby (2001) define nine strategies based on knowledge to maximise the addition of value within an organisation, resulting from the interaction between these nine strategies as mentioned before, illustrated in Figure 1.

Organisations seek to improve the transfer and conversion of knowledge between the three families of intangible assets (external structure, internal structure and individual competence), so that the ability for people to act, both within and outside the organisation, is increased. External structure: this can be seen as a family of intangible relationships with clients and suppliers, which is the base for the reputation (corporate image) of the company. The value of such intangible assets is influenced mainly by how well a company solves the problems of its clients, which could involve an uncertainty element. Internal structure: this can be seen as the maintenance of patents, concepts, models, processes, information systems

eGesta - Revista Eletrônica de Gestão de Negócios - ISSN 1809-0079

Mestrado em Gestão de Negócios - Universidade Católica de Santos

Facultade de Ciencias Económicas e Empresariais - Universidade de Santiago de Compostela 
and other more explicit management tools. These are created by the employees and are normally absorbed, in which case the organisation acquires the "ownership" thereof. The informal power game, the internal networks and culture can also be considered as part of the internal structure. Individual Competence: this is represented by the vision of the technical and professional staff, on the one side, and the support and administrative personnel, including people from $R \& D$, from processes, sales and commercialisation or, in short, those who have direct contact with, or direct influence on, the clients of the organisation. The distinctions between professional staff and support and management personnel are made because their roles are different and they establish how they relate to each other.

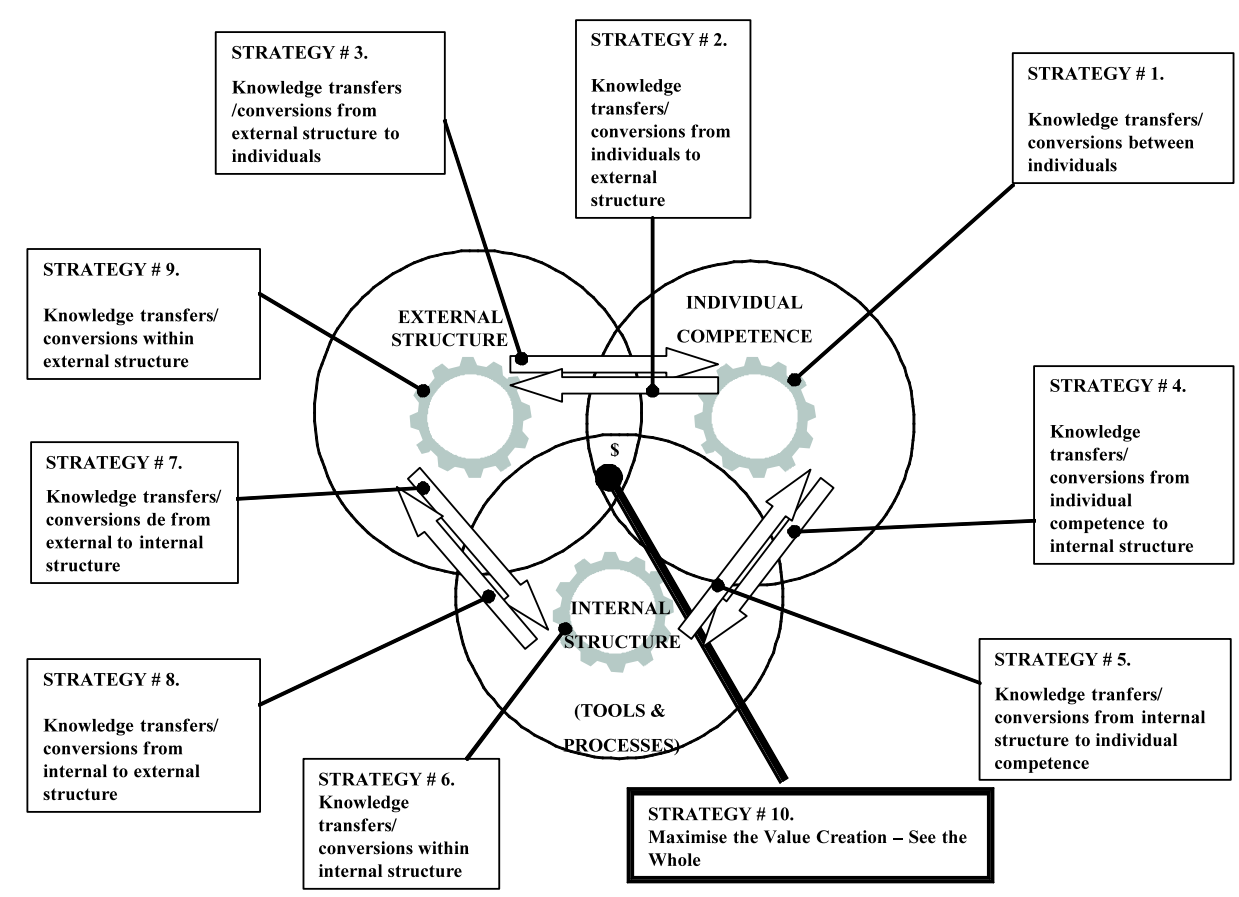

Figure 1. Knowledge-based strategy. Adapted from Sveiby, Linard and Dvorsky (2002) and Sveiby (2001)

eGesta - Revista Eletrônica de Gestão de Negócios - ISSN 1809-0079

Mestrado em Gestão de Negócios - Universidade Católica de Santos

Facultade de Ciencias Económicas e Empresariais - Universidade de Santiago de Compostela 
The creation of value may be better understood through the systematic interrelationship between these three families of intangible assets, and the nine knowledge strategies associated to them. The tenth strategy is the maximisation of value added (Figure 1). This construct has been used in the present empirical research.

\section{Methodology}

As Eisenhardt (1989) recommends a "prior specification of constructs ... to shape the initial design of theory building research", the subsection 2.2 defines the key concepts used in this research and gives the operationalisation of these concepts. The concepts for this research are mainly based on dynamic approach to Knowledge-Based Strategies (Figure 1). This theoretical proposition shall be used for the conduction of the research project, collection and data analysis, and has been adapted from the knowledge-based strategy model (KBV) developed by Sveiby, Linard and Dvorsky (2002) and Sveiby (2001).

The methodology used for the development of this research was that of multiple case studies, which may be defined as an "empirical inquiry that investigates a contemporary phenomenon within its real-life context, especially when the boundaries between phenomena and context are not clearly evident." (YIN, 1994, p.13). The data used in this work has been obtained from both primary and secondary sources. The main secondary sources include: publications in internal reports of Camargo Corrêa Cimentos and Loma Negra, Votorantim Cimentos and St Mary's; industrial studies and profiles of domestic players such as Votorantim Cimentos and international ones like Cemex (a Mexican Cement MNC), as well as information sources within the cement industry such as the American Cement Directory,

Gesta - Revista Eletrônica de Gestão de Negócios - ISSN 1809-0079

Mestrado em Gestão de Negócios - Universidade Católica de Santos

Facultade de Ciencias Económicas e Empresariais - Universidade de Santiago de Compostela 
Cement Standards of the World, Global Cement Report; articles in proceedings and journals about strategy and the cement industry specifically, including Cement International and the International Cement Review. The sources also include the Camargo Corrêa Magazine with information about plans, policies and business investments, and the statistical supplement issued by the Asociation de Fabricantes de Cemento Portlant de Argentina Portland Cement Producers Association of Argentina), and by the Associação Brasileira de Cimentos Portlant (Brazilian Portland Cement Association - ABCP). The primary sources have been the result of key informants' interviews chosen by the researchers because of a strong knowledge of the issue being studied. These interviews made with employees and collaborators of Camargo Corrêa Cimentos and Votorantim Cimentos, including managers, executives and business partners. The semi-structured interviews were made in person, by telephone or exchange of emails, the period of data collection having gone from December 2005 and April 2006, after the approval of the purchase of Loma Negra assets. The data has been updated to the end of 2007. Complete anonymity of the interviewees has been maintained at all times.

The data collected has been analysed by the document analysis technique and using content analysis, in descriptive and qualitative manner (MARSCHAN-PIEKKARI; WELCH, 2004).

\section{The cement industry}

At the outset, this sector depends on reserves of limestone of high quality that can meet the demands of the consumer market. However, the availability of raw materials is not a determining factor for a competitive advantage, as such supplies are abundant in almost the

eGesta - Revista Eletrônica de Gestão de Negócios - ISSN 1809-0079

Mestrado em Gestão de Negócios - Universidade Católica de Santos

Facultade de Ciencias Económicas e Empresariais - Universidade de Santiago de Compostela 
whole world. The production units should preferably be in locations with availability of transport to the large consumer centres. There are industrial consumers (concrete mills, artefacts) and final use (building firms, construction development firms, and the final consumer).

The cement industry is considered to be an activity of intense capital, and it is estimated that, currently, in the case of larger plants, the specific investments needed lie around the level of US\$90/tonne of clinker per annum (CAUÊ, 2006), covering equipment and buildings (but not including sites, deposits of limestone and operating capital).

The technology, widely used in the world, reached significant development up to the 1980s, remaining stable in the last two decades.

The installation of the industrial units depends on the proximity of limestone deposits. The features of the cement industry also encourage associations and acquisitions involving companies of this segment (GHEMAWAT; THOMAS, 2005). However, in certain countries, competition issues limit the consolidation of the market. One feature of the world cement market is a trend towards local consumption, close to the factories, due to factors such as the low value of the product in relation to its weight, the fact that cement is perishable, and the high cost of freight. Nowadays, cement attains homogeneous standards of quality, standardised in line with national and international regulations. Another important trend of this segment is its virtualization, which means that it is starting to act directly in the activity of production of concrete and mortar, combining industrial activity with the provision of services with benefit for the clients. One successful example of this strategy is the activity of Votorantim Cimentos (VC) and its operational base in the Great Lakes region, serving the markets in the United States and Canada, where their presence is a decisive factor in addition

eGesta - Revista Eletrônica de Gestão de Negócios - ISSN 1809-0079

Mestrado em Gestão de Negócios - Universidade Católica de Santos

Facultade de Ciencias Económicas e Empresariais - Universidade de Santiago de Compostela 
of value for the clients, including concrete mills, addition mills and logistical operations (Hutton Transport).

The distribution and consumption channels for cement are the points of sale, industrial consumers (concrete mills, fibrocement, pre-moulded, artefacts and mortar) and the final consumer (construction companies and Government institutions). In Latin America, different from the case of the United States and Canada, most of the production goes to the points of sale (normally shops selling building materials), while there is a quest for a gradual rise in the participation of industrial consumers.

In the global cement market, China is the largest market in the world with a market share of about $36 \%(\mathrm{GCR}, 2005)$, while Brazil is in $11^{\text {th }}$ position in the world league with $2 \%$ of the market (GCR, 2005). The concrete and cement world markets are consolidated and developed, and is now under the control of large multinational industrial groups that have a significant share of the market and much of the turnover related to this segment.

The Latin American market has one of the most promising growth potentials of the world, as the region has a low consumption per capita, and shortcomings that shall require investment in the building of houses and infrastructure. Within Latin America, South America has about $61 \%$ of the total production of cement. Looking at the South American scene, we see that the Brazilian production stands out, with more than $55 \%$ of the total production of the region. The per capita consumption of cement in Brazil (190 kg per person) and Argentina (140 kg per person) is still very low in comparison with the consumption in developed countries like the United States (390 kg/person) (GCR, 2005). Brazil and Argentina have markets with excellent prospects for growth, a fact that occurs in only a few parts of the world.

eGesta - Revista Eletrônica de Gestão de Negócios - ISSN 1809-0079

Mestrado em Gestão de Negócios - Universidade Católica de Santos

Facultade de Ciencias Económicas e Empresariais - Universidade de Santiago de Compostela 


\section{The cement groups analysed}

\subsection{Camargo Corrêa Cimentos (CCC)}

The history of CCC started back in 1968, under the name of Camargo Corrêa Industrial S.A., to act specifically in the cement market. In 1969 the project for the construction of the first production unit was approved and, in 1974, the Apiaí Plant was opened. In July 1993, CCC acquired the Bodoquena Plant and, four years later, purchased a controlling stake in Cimento Cauê S.A. and the Plants in Pedro Leopoldo and Santana do Paraíso. In 1998 Camargo Corrêa Industrial S.A. took over Cimento Cauê S.A., thence taking on the new name of Camargo Corrêa Cimentos S.A. (CCC). In 2000, CCC launched white cement under the brand name "Cauê", starting its internationalization process with exports (the entry strategy). In 2002, CCC started to be present in the concrete segment, offering distinctive services to their clients, as also the possibility of tracking the location of their concrete mixers through the Internet, and a certificate of technological control. On April 2003, CCC inaugurated their largest and most modern unit for cement production, the Ijaci Plant, with a production capacity of about 1.9 million tonnes of cement a year.

The company has a participation of some $8 \%$ in the Brazilian market. The growth in the sales of white cement and concrete compensates for possible drops in sales of grey cement. Indeed, $\mathrm{CCC}$ is market leader in white cement.

The international companies in which CCC has a stake include: Itacamba Cemento S.A., based in Santa Cruz de La Sierra, Bolivia, in which main activities are the crushing of cement and other mineral products and the import and commercialisation of cement and cement products in Bolivia; Yguazu Cementos S.A., in the city of Asuncion, Paraguay, in which main

eGesta - Revista Eletrônica de Gestão de Negócios - ISSN 1809-0079

Mestrado em Gestão de Negócios - Universidade Católica de Santos

Facultade de Ciencias Económicas e Empresariais - Universidade de Santiago de Compostela 
activity is the import and commercialisation of cement and cement products. As is the case with Itacamba Cemento S.A., many of the products that Yguazu Cemento S.A. imports comes from cement plants in Brazil, with a participation of about $20 \%$ on the Paraguayan market.

There is also a stake in Minas Gerais Steel (Usinas Siderúrgicas de Minas Gerais S.A. USIMINAS), this company being an important supplier of slag for CCC.

\subsection{Loma Negra}

Alfredo Fortabat founded Loma Negra in Argentina in 1926. The main business activity is the production of grey cement, plain concrete and lime products. The company is also the controller of Cementos del Plata S.A. a joint venture selling cement in Uruguay.

During the nineties, the cement industry in Argentina was consolidated after a spate of acquisitions of several producers. In 1992 (operation consolidated in 2000) there was the purchase of Cemento San Martin, with the cement-producing plant at Sierras Bayas, with a total production capacity of 1.0 million tonnes, and a crushing plant in Paraná (Entre Rios) with a annual cement production capacity of 250,000 tonnes. As part of the strategy to acquire other business opportunities within the cement industry, as also to diversify the existing business activities, Loma Negra acquired operations in plain concrete from several cement producers in Greater Buenos Aires and also in the city of Rosario in 1998. All these activities have been grouped under the controlled company, the Compañia de Servicios a la Construcción S.A. ("Servicon") under the Lomax brand. Servicon is one of the leading companies in plain concrete within the areas mentioned above, and has specialised in large construction projects, having a wide range of products in concrete specialities. 
The products are sold under the "Loma Negra" brand, one of the best-known brands of cement in Argentina. In Argentina, the products are sold loose and then put in bags (about $70 \%$ ), in a situation similar to that of the Brazilian market where CCC sells some $75 \%$ of production in bags. The products conform to both American and European quality standards (American Society for Testing Materials - ASTM and the International Organisation for Standardisation - ISO respectively).

Loma Negra is the most important cement producer in Argentina, having been market leader for over 75 years. In 2004, they had a market share of $45.8 \%$ of that of all cement producers in Argentina, while at the start of 2006 their market share came to around $48 \%$. On 30 June 2005, Camargo Corrêa S.A. (CCSA) celebrated a contract of purchase and sale, to acquire the full capital stock of Holdtotal S.A., the holding company that had a stake of about $70 \%$ of the capital stock of Loma Negra. Later, CCSA celebrated other contracts with other organisations to acquire essentially all the circulating capital. The price of this purchase was U\$S 1.025 billion and the deal were approved by the National Competency Defence Commission (Comisión Nacional de Defensa de la Competencia) on 11 October 2005.

CCC and Loma Negra are the companies responsible for the CCSA operations in Brazil, Paraguay, Bolivia (CCC) and in Argentina and Uruguay (Loma Negra), concentrating their efforts on implementation and on a management system for the improvement of industrial processes.

eGesta - Revista Eletrônica de Gestão de Negócios - ISSN 1809-0079

Mestrado em Gestão de Negócios - Universidade Católica de Santos

Facultade de Ciencias Económicas e Empresariais - Universidade de Santiago de Compostela 


\subsection{Votorantim Cimentos and their operations in North America}

The history of Votorantim Cimentos (VC) started in 1936 with the inauguration of the Santa Helena Cement Factory, in the interior of the Brazilian State of São Paulo. Since then, investment has been made in the company's plants, with the aim of adapting the production to the consumer market. VC is the holding that brings together cement, lime, and concrete and mortar companies in Brazil and abroad. The first step on the path to internationalisation of the company was taken with the purchase, in 2001, of St Mary's (Canada) from Lafarge. At the start of 2003, the company acquired 50\% of Suwannee American Cement, based in Florida (United States), the other $50 \%$ of this joint venture belonging to Anderson Columbia, a civil engineering company that built the factory and has Votorantim as a partner from the cement segment, in the management of their operations.

The company also has a 50\% stake in concrete producer Trinity Materials. That same year of 2003, there was the conclusion of the deal for the purchase of the assets of Badger Cement Products, a cement-crushing firm in the city of Milwaukee, Wisconsin. In 2004 there was the purchase of S\&W Materials Inc, in Jacksonville, one of the largest concrete companies in Florida. In 2005, the company acquired some assets of Cemex, including two plants in the Great Lakes region (Illinois and Michigan). The company currently has four cement factories, a cement-crushing unit in Detroit (United States) and another in Wisconsin (United States), eight terminals for the distribution of cement in the American region around the Great Lakes and 39 concrete mills (Canada Building Materials) in the Canadian province of Ontario.

eGesta - Revista Eletrônica de Gestão de Negócios - ISSN 1809-0079

Mestrado em Gestão de Negócios - Universidade Católica de Santos

Facultade de Ciencias Económicas e Empresariais - Universidade de Santiago de Compostela 
On the world stage, the company ranks among the ten largest producers of cement and is ahead of other competitors with a global presence. In North America, VC has a market share of $30 \%$ in the Great Lakes region. The total investment made in the region has surpassed the US\$ 1.3 billion mark. As a unit, VC has about 8,000 employees, of which 1,700 are based abroad, and a total production capacity of 4.5 million tonnes in North America.

\section{A business model for value creation}

Grant (2001, p.145) discusses "Business is concerned with creating value. The challenge for business strategy is ensuring that a significant proportion of this value creation is appropriated in profit. Business creates value in two ways: commerce and production. Commerce involves arbitraging commodities in space and time. Thus, commerce includes trade, whereby a commodity is transferred from a location where it is less valued to a location where it is more valued.

Production involves the physical transformation of commodities from something that is less valued ... to something that is more valued". Being active in a highly competitive market, in Brazil and abroad, the Brazilian cement producing companies have grand targets: to be the largest producers of cement in Latin America and to have more of an international presence. In the development of their strategic plan, the cement companies have a "Strategy Management" that sets targets and objectives in the long term, always in agreement with the strategic planning made by their controlling companies (Camargo Correa and the Votorantim Groups), anticipating technical, economic and financial situations and setting reference indicators (benchmarks) for the implementation of these strategies. The main strategies to

eGesta - Revista Eletrônica de Gestão de Negócios - ISSN 1809-0079

Mestrado em Gestão de Negócios - Universidade Católica de Santos

Facultade de Ciencias Económicas e Empresariais - Universidade de Santiago de Compostela 
meet the aforementioned targets are: to grow through acquisitions, mergers and strategic alliances - in Brazil, North America (the United States and Canada), Argentina, and other Latin American countries. The companies monitor the Brazilian and international markets in search for opportunities for acquisitions, joint ventures and other forms of strategic alliances, with gain of synergy and productivity, giving priority to strategic markets with good potential for growth, such as the case of Argentina, or mature markets (North America). The current forecast is that there shall be a growth in operations in Argentina, where 7.3 million tonnes were sold in 1999, a volume which plummeted to 3.7 million tonnes at the height of the Argentinean crisis.

In the short term, the cement companies look into possibilities of acquisitions, but without forsaking the chance of joint ventures and other forms of association. With this strategy, they hope to have a rise in participation in the market, as well as optimising their processes of production and management (integrating production capacity and unified management). With purchase opportunities in foreign markets, the cement factories also intend to boost their participation in the international cement markets, especially in America as a whole, as also a diversification of income in foreign currency.

The tarrif and shipping costs discourage the exporting for this industry as cited by Govindarajan and Gupta (2001, p.32) “... shipping and tariff costs are so high as to neutralize any cost advantages associated with producing in any country other than the target market. This is the primary reason that cement companies such as Cemex and Lafarge rely heavily on local production in the countries that they have entered". The reduction of costs and a rise in efficiency are the main operational aims, closely monitoring the cement and supplies markets and planning the purchase of such supplies according to their analysis and forecasts, as well 
as establishing cost targets and purchase methodologies for the best usage of opportunities and favourable market conditions. Gains in scale and scope, including exports and imports between companies in the each group, are also part of this strategy.

\section{Development of strategic skills}

In this section, we present the three families of intangible assets that make up the development of the essential skills mentioned in the theoretical construct of the KBV (Figure 1).

\subsection{Assets of External Structure}

These refer to client portfolios, relationships with suppliers, sister companies, joint ventures and shareholders, and are linked to co-operation agreements, strategic, commercial, production and technological alliances, trademarks and the company image. These assets are company property and some may be legally protected (for example, trademarks).

\subsection{Assets of Internal Structure}

These concern the formal and informal structure of the organisation, the work methods and procedures, the software, databases, $R \& D$, management and planning systems, and the culture of the organisation of knowledge. These assets are company properties and some may be legally protected (patents, intellectual property and so forth). Among the main indicators of

eGesta - Revista Eletrônica de Gestão de Negócios - ISSN 1809-0079

Mestrado em Gestão de Negócios - Universidade Católica de Santos

Facultade de Ciencias Económicas e Empresariais - Universidade de Santiago de Compostela 
internal structure, we could highlight growth or renewal, investment in technologies and information systems, and the dedicated tasks for clients who may improve the internal structure.

In relation to $R \& D$, one example is the research centre of Loma Negra in Buenos Aires, that develops products with cutting-edge technology, yet unheard of in the Argentinean market, such as, for example, high-performance concrete. In Argentina, for example, petrol cement of high resistance is produced, to be used as coating for oil wells, this being a product not produced in Brazil.

\subsection{Assets of Individual Competence}

The concept of competence is the best way of describing knowledge within business contexts, and is also the most important element within the intangible assets (SVEIBY, 1998). It may be passed on from one person to another, through information or tradition (practical community). Competence is not only one of the three intangible assets within an agile organisation, but is also the source of the internal and external structures. They refer to aspects such as education, experience, expertise, general knowledge, skills, values and attitudes of the technical, support and administrative staff. They are not owned by the company. The company hires the use of such assets with their employees, which take such assets with them when they go home.

One example of the development of competencies involving the community is that of the CCC, who sponsor projects such as the project developed at the Pedro Leopoldo Plant, in Minas Gerais state, which took 150 professional people in, and put them in refresher courses

eGesta - Revista Eletrônica de Gestão de Negócios - ISSN 1809-0079

Mestrado em Gestão de Negócios - Universidade Católica de Santos

Facultade de Ciencias Económicas e Empresariais - Universidade de Santiago de Compostela 
given by the local Senai, with the aim of qualifying professionals skilled in mechanical, electrical and electronic maintenance for industrial firms in the region, to improve service provision.

An example of the development of internal competences on the purchase of Loma Negra was the phase of Due Diligence, and later an integration programme, involving more than forty professionals from different areas within the group.

\section{Data analysis}

In this section, we present a summary of the data obtained in the survey mentioned in the previous section of this report. Use shall be made of the nine strategies named - and duly numbered - of the theoretical construct of KBV (Figure 1), which add value for the organisation. The maximisation of addition of value arises from the interaction of these forces that illustrate the importance of integration of all these activities into one strategic framework. There is also mention of some of the main representative actions for knowledge strategies of CCC, VC, St. Mary's and Loma Negra, which does not in itself exhaust the model, in large and complex organisations such as those involved in the current work.

\subsection{Analysis of the three families of intangible assets}

Strategy \#1. This refers to the communication between individuals within the organisation, in teamwork, with learning and knowledge sharing. One significant feature of this strategy is the trainee programme conducted in Brazil, by Camargo Correa Group and

eGesta - Revista Eletrônica de Gestão de Negócios - ISSN 1809-0079

Mestrado em Gestão de Negócios - Universidade Católica de Santos

Facultade de Ciencias Económicas e Empresariais - Universidade de Santiago de Compostela 
Votorantim Group, with the support of teams of specialised professionals who are responsible for providing a wide view of the business, its strategies and processes. These actions also help towards the renewal of the groups analysed, preparing professional people to take on strategic positions in other operations, including abroad. Other desirable competences include sharing experiences with the team; thinking about quality; exercising a constant search for challenges; mastery of the Spanish and English languages. The groups are constantly training their employees with the aim of developing the skills that are necessary to operate in cement companies of large size and steady growth.

Votorantim has a trainee programme 18 months in length, and the requirements for this programme include fluent English and some computer knowledge. The participants in the programme develop projects that help towards the constant improvement in business management. The main purpose of the programme is to select and develop new talent, providing opportunities for growth within the company. Some former trainees now occupy management posts.

The Due Diligence programme and later phases, within the purchase of Loma Negra, is a representation of an integration of such assets.

Strategy \#6. One important characteristic here is the reuse of knowledge existing within internal structure of the groups. There have been internal benchmark actions and transfer to world-class standards. There is a declaration of a corporate strategic plan in the long term and its dissemination to all units, in all countries where the groups are active, as also tools that are part of one of their "Business Systems".

Examples are the business management systems that have enabled the improvement and centralisation of the management information systems, also including administrative, 
accounting, purchasing systems, as also client management and control. Quality programmes have been implemented (Six Sigma and Total Quality), and, in addition, this segment meets technical standards such as ISO. For VC, there is the Votorantim Cimentos Business Systems (VCBS) that consider a management model for production operations, and the Votorantim Cimentos Production System (VCPS) which uses techniques such as Six Sigma.

Strategy \#9. This refers to knowledge transfers within the external structure. Issues such as the business models of the cement plants and the technological development of their main suppliers, specific needs of the clients, and new techniques for construction, such as the preparation of concrete with features defined by the client. Here, it is important to stress the complementarity between the cement production activities and the commercialisation thereof and addition of value there to, such as plain concrete, where the competences that are necessary to carry out activities with the client are developed by the downstream or verticalisation operations, as seen, the contracts and "partnerships" between companies controlled by the controlling companies.

\subsection{Analysis of knowledge flows between individuals and external structure}

Strategy \#2. One good example of this strategy is that of clients such as the case of the usage of the Internet to provide distinctive service to the clients, such as the possibility to monitor the location of the cement mixers via the World Wide Web (Internet). The existing technical knowledge for meeting specific demands made by the clients, as the case of petrol cement or in the case of transfer of the technology in the use of coke from the Brazilian operations of CCC to the Argentinean ones.

eGesta - Revista Eletrônica de Gestão de Negócios - ISSN 1809-0079

Mestrado em Gestão de Negócios - Universidade Católica de Santos

Facultade de Ciencias Económicas e Empresariais - Universidade de Santiago de Compostela 
Strategy \#3. This is the learning of current and future needs of the companies within this segment, sensitive to price and alterations in demand by the markets, as also the understanding of the business model, the strategies and the steps made by competitors and the main players of the market, the follow-up on the economic and political situations of the countries in which the Brazilian cement companies are active.

\subsection{Analysis of knowledge flows between Internal and external structures}

Strategy \#7. This refers to what knowledge can be acquired from the external world to the internal structure, via benchmark, with regard to the competences of clients, suppliers and other shareholders, thereby improving systems, tools, processes and products. The partnership that exists between CCC and key suppliers, such a Usiminas, for slag, or that of Loma Negra with Ferrosur are essential for the integrated efficiency of a cement factory, and, in this case, one of its strategic guides. For the cement industry in North America, the suppliers of equipment operate globally and have no exclusivity contract, while the solutions are given based on the technical knowledge of the suppliers and of technicians from the cement industry.

Strategy \#8. This refers to knowledge transfers from internal to external structure. As part of the strategy that seeks to uphold their image on the international market, the Brazilian cement producers need their web systems to always be in operation. Collaborators make use of the extranet of the company for operations involving B2B e-commerce. There are systems enabling monitoring by the clients.

eGesta - Revista Eletrônica de Gestão de Negócios - ISSN 1809-0079

Mestrado em Gestão de Negócios - Universidade Católica de Santos

Facultade de Ciencias Económicas e Empresariais - Universidade de Santiago de Compostela 


\subsection{Analysis of Conversions between Individual Competences and the Internal Structure}

Strategy \#4. This refers to knowledge transfers from individual competence into internal structure. This is where tacit knowledge is stored in repositories. The idea is that this knowledge may be shared by the whole organisation. This knowledge may be observed through the Intranet, through the document management systems, based on the implicit knowledge of employees and external collaborators, including consultants. The use of the CCC management model in the dissemination of internal knowledge has an important role, as also do the thematic discussion groups on VC's Intranet and on their e-library.

Strategy \#5. This is the converse of the previous strategy (\#4). Once the competence has been captured, it needs to be made available to other individuals. The key for the addition of value is the information that generates competence. E-learning environment and knowledge management systems are included in this strategy, as also are benchmarks and best practices within the units of CCC and of the business group (CCSA). The "Knowledge Channel" of VC is available for the 7 thousand or so employees of the company in Brazil, and since 2004, the electronic tools for knowledge management and corporate education have migrated from the Intranet to the Web, to meet the needs of some 1.6 thousand-company employees in the United States and in Canada. These knowledge management tools have enabled the replication of processes and exchange of experiences. In the case of $\mathrm{VC}$, it has been essential for the dissemination of the VCBS - Votorantim Cimentos Business System.

eGesta - Revista Eletrônica de Gestão de Negócios - ISSN 1809-0079

Mestrado em Gestão de Negócios - Universidade Católica de Santos

Facultade de Ciencias Económicas e Empresariais - Universidade de Santiago de Compostela 


\section{Conclusions}

For the core competences in the Brazilian Cement industry, the table 1 sums up these ideas for Camargo Correa and Votorantim Groups. According to Prahalad and Hamel (1990), a diversified corporation is like a large tree. The trunk and major limbs are core products; the smaller branches are business units; and the leaves, flowers, and fruit are end products. As the root system provides nourishment and stability for the tree and in that way keeps it alive, the root system of a corporation has the greatest power. In a corporation, the root system is the core competence.

This core competences in cement industries goes from domestic to international markets as cited by Wernerfelt (2001, p.176) “... to expand your position in a single resource, it is not always optimal to go full force in several markets simultaneously even with experience curve effects. Quite often, it is better to develop the resource in one market and then enter other markets from a position of strength."

Table 1. Brazilian Cement MNCs' Competence Tree. Prepared by the authors based on a concept of Prahalad and Hamel (1990)

\begin{tabular}{|l|l|l|}
\hline Fruit & End Products & $\begin{array}{l}\text { Grey cement, white cement, non-structural white cement, basic and } \\
\text { special concrete, lime. }\end{array}$ \\
\hline Branches & Business Units & $\begin{array}{l}\text { Camargo Correa Group: Camargo Corrêa Cimentos ( Brazil ), Loma } \\
\text { Negra (Argentina), Cementos del Plata ( JV Loma Negra in Uruguay), } \\
\text { Itacamba Cemento S.A (Bolivia), Yguazu Cementos S.A. ( Paraguay). } \\
\text { Votorantim Group: Votorantim Cimentos (Brazil), St Mary's Cement, } \\
\text { St Mary's CBM (Canada Building Materials) (Canada), Suwannee } \\
\text { American Cement (50\%), Trinity Materials (50\%), Badger Cement } \\
\text { Products, S\&W Materials Inc. }\end{array}$ \\
\hline Trunk & Basic Products & $\begin{array}{l}\text { Cement, mortar and lime. Concrete (conventional, fibre, heavy, paving, } \\
\text { high performance etc) }\end{array}$ \\
\hline Roots & $\begin{array}{l}\text { Organisational } \\
\text { Competences }\end{array}$ & $\begin{array}{l}\text { Strategic location, cutting-edge technology, professional management, } \\
\text { long-term operations and contracts (supplies, energy and logistics) }\end{array}$ \\
\hline
\end{tabular}

eGesta - Revista Eletrônica de Gestão de Negócios - ISSN 1809-0079

Mestrado em Gestão de Negócios - Universidade Católica de Santos

Facultade de Ciencias Económicas e Empresariais - Universidade de Santiago de Compostela 
Starting out from the lines of thought that deal with competitive advantage arising from internal resources (RBV), several theoretical lines specifically dealing with knowledge and the flow thereof (KBV) have appeared, and these studies unanimously say that this theme has several aspects still to be discovered. The proposed theoretical model could be tested for Camargo Correa and Votorantim Groups. In this way, the strategy of maximisation of knowledge, resulting from the interaction of forces of this model, could be tested for Camargo Correa and Votorantim Groups, organisations that are building competitive advantage based on knowledge, using a clear strategy of collaboration and knowledge sharing, with active participation of their main suppliers and clients, as well as activity, in a joint venture, and establishment of flows and permanent networks of information exchange and knowledge, which are steps that are essential for a successful strategy.

It can be said that Camargo Correa and Votorantim Groups presents knowledge as a strategic resource, and the skill in its creation and application is an important skill for the generation of a competitive advantage and also value for the shareholder. From this point of view, there is a connection between knowledge and the business strategy for the whole of Camargo Correa Group, as also for Votorantim Groups and, as they have links between their operations and owned companies (or joint ventures) in the countries are Latin America and North America where they are active. Organisations that value the development of their core competences open the possibility of development of a culture that allows the creation of strategies based on knowledge, creating conditions so that a competitive advantage may be obtained, and so that value may be added. Within the framework presented in this research, a firm's current strategy involves choosing optimal combination of knowledge flows, whereas

eGesta - Revista Eletrônica de Gestão de Negócios - ISSN 1809-0079

Mestrado em Gestão de Negócios - Universidade Católica de Santos

Facultade de Ciencias Económicas e Empresariais - Universidade de Santiago de Compostela 
its competitive position and hence its potential profitability is determined by the level of its knowledge flows.

For Camargo Correa and Votorantim Groups, the creation of measurement and monitoring of the three families of assets and the nine strategies of the construct, as used in this research, may help towards an effective advancement in the follow-up on long-term strategic decisions, showing the progress in each strategy. Within the limitations of the present research, and as a suggestion for future studies, we propose the testing of other KBV models (GRANT, 1996; EISENHARDT; SANTOS, 2002) for Camargo Correa and Votorantim Groups, and the expansion of the scope of this research to cover the specific theories of internationalisation and that represent the mainstream of the area, such as the works of Johanson and Vahlne (1977) and Kogut and Zander (1992; 1993). It is intended that this work may contribute to the debate about an issue $(\mathrm{KBV})$ that is developing at full throttle within the field of corporate strategy and knowledge flows in MNCs.

\section{References}

ADLER, N.; HASHAI, N. Knowledge flows and the modelling of the multinational enterprise, Journal of International Business Studies, v.38, n.4, p.639-657. 2007.

AsSOciaÇão Brasileira DE Cimento PorTLAND. http://www.abcp.org.br. Accessed 15 December 2005

BARNEY, J.B. Firm resources and sustained competitive advantage. Journal of Management. v.17, p.99-120. 1991.

eGesta - Revista Eletrônica de Gestão de Negócios - ISSN 1809-0079

Mestrado em Gestão de Negócios - Universidade Católica de Santos

Facultade de Ciencias Económicas e Empresariais - Universidade de Santiago de Compostela 
; ARIKAN, A. M. The Resource-based View: Origins and Implications In: HITT, M. A., FREEMAN, R.E.; HARRISON, J.S. (eds.), The Blackwell Handbook of Strategic Management. Oxford:Blackwell. 2001.

BIERLY, P.E.; CHAKRABARTI, A.K. Technological learning, strategic flexibility, and new product development in the pharmaceutical industry. IEEE Transactions on Engineering Management, v.43, n.4, 1996, p.368-380. 1996.

BCG. The New Global Challengers: How 100 Top Companies from Rapidly Developing Economies Are Changing the World. BCG Report. May 2006.

. The 2008 BCG 100 New Global Challengers: How Top Companies from Rapidly Developing Economies Are Changing the World. BCG Report. December 2007.

CAMARGO CORRÊA REVISTA. Revista Camargo Corrêa, 2nd Quarter of 2005, Year VII, n.30. 2005.

CAMARGO CORREAA CIMENTOS. www.camargocorrea.com.br. Accessed 15 January 2006.

CAUÊ. www.caue.com.br. Accessed 15 January 2006.

COLLIS, D. J.; MONTGOMERY, C. A. Competing on Resources: Strategy in the 1990s. Harvard Business Review. July-August 1995,p.118-128. 1995.

DEMSETZ, H. The Theory of the Firm Revisited, In: O. E. WILLIAMSON, S. G. WINTER (eds.), The Nature of the Firm. Oxford University Press:New York. p.159-178. 1991.

EISENHARDT, K. Building Theories from Case Study Research. Academy of Management Review, v.14, n.4, p.532-550. 1989.

EISENHARDT, K.; SANTOS F. Knowledge-Based View: A New Theory of Strategy? In: PETTIGREW, A.; THOMAS, H.; WHITTINGTON, R. (eds.), Handbook of Strategy and Management. Sage:London. 2002.

eGesta - Revista Eletrônica de Gestão de Negócios - ISSN 1809-0079

Mestrado em Gestão de Negócios - Universidade Católica de Santos

Facultade de Ciencias Económicas e Empresariais - Universidade de Santiago de Compostela 
FDC. Ranking FDC das Transnacionais Brasileiras - Edição 2008. Nova Lima:Fundação Dom Cabral. 2009.

FOSS, N.J.; PEDERSEN, T. Transferring knowledge in MNCs The role of sources of subsidiary knowledge and organizational context. Journal of International Management. v.8,n.1,p.49-67. 2002.

GCR: GLOBAL CEMENT REPORT. http://www.cemnet.com/public/ publication/publicationDet.asp?id=13 Accessed 12 December 2005.

GHEMAWAT, P.; THOMAS, C. Multinational Agglomeration in the Cement Industry: Patterns, Drivers, and Performance Implications, working-paper, Boston: Harvard Business School. 2005.

GOVINDARAJAN, V.; GUPTA, A.K. Global Dominance: Transforming Global Presence into Global Competitive Advantage. Jossey-Bass:San Francisco. 2001.

GRANT, R.M. Toward a Knowledge-Based Theory of the Firm. Strategic Management Journal, v.17, p.109-122. 1996.

Knowledge and Organization. In: NONAKA, I.; TEECE, D. (eds). Managing Industrial Knowledge: Creation, transfer and utilization. Sage:London. 2001.

GUPTA, A.K.; GOVINDARAJAN, V. Knowledge Flows and the Structure of Control within Multinational Corporations. Academy of Management Review. v.16, n.4, p.768-792. 1991.

Knowledge Flows within Multinational Corporations. Strategic Management Journal. v.21, n.4, p.473-496. 2000.

JOHANSON, J.; VAHLNE J.E. Internationalization Process of Firm: Model of Knowledge Development and Increasing Foreign Market Commitments, Journal of International Business Studies, v.8, n.1, p.23-32. 1977.

KOGUT, B. \& ZANDER, U. Knowledge of the firm, combinative capabilities, and the replication of technology, Organization Science, v.3, n.3, p.383-397. 1992. 
. Knowledge of the firm and the evolutionary theory of the multinational corporation,

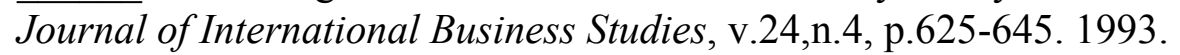

LAGERSTRÖM, Katarina; ANDERSSON, Maria. Creating and sharing knowledge within a transnational team - the development of a global business system. Journal of World Business. v.38, n.2, p.84-95. 2003.

LOMA NEGRA. www.lomanegra.com.ar Accessed 15 January 2006.

LONDON, T.; HART S.L. Reinventing strategies for emerging markets: beyond the transnational model, Journal of International Business Studies, v.35, n.5, p.350-370. 2004.

OETTL, A.; AGRAWAL, A. International labour mobility and knowledge flow externalities, Journal of International Business Studies. v.39, n.8, p.1242-1260. 2008.

MARSCHAN-PIEKKARI, Rebecca; WELCH, Catherine. (eds.) Handbook of Qualitative Research Methods for International Business. Edward Elgar Publishing. 2004.

MUDAMBI,R.; NAVARRA, P. Is knowledge power? Knowledge flows, subsidiary power, and rent-seeking within MNCs, Journal of International Business Studies, v. 35, n.5, p.385406. 2004.

PETERAF, M.A. The Cornerstones of Competitive Advantage: A Resource-Based View. Strategic Management Journal. v.14, p.179-188. 1993.

PORTER, M.E. Competitive Strategy: Techniques for analyzing Industries and Competitors. The Free Press:New York. 1980.

PRAHALAD, C.K.; HAMEL, G. The core competence of the corporation. Harvard Business Review, 1990, v.68, n.3, p.79-91. 1990.

SPENDER, J.C. Making Knowledge the Basis of a Dynamic Theory of the Firm. Strategic Management Journal, 1996, v.17, p.45-62. 1996.

SPENDER, J.C.; GRANT, R.M. Knowledge of the Firm. Strategic Management Journal, v.17, p.5-9, 1996. 
SVEIBY, K. E. The New Organizational Wealth: Managing and Measuring KnowledgeBased Assets, Berrett-Koehler Publishers. 1997.

SVEIBY, K.E. A knowledge-based theory of the firm to guide in strategy formulation. Journal of Intellectual Capital, v.2, n.4, p.344-358. 2001.

; LINARD K.;DVORSKY L. Building a knowledge based strategy: A system dynamics model for allocating value added capacity. Palermo, Italy: In 20th International Conference of the System Dynamics Society Proceedings. 2002.

TEECE, D. Strategies for Managing Knowledge Assets: the Role of Firm Structure and Industrial Context. In: NONAKA, I.; TEECE, D. (eds). Managing Industrial Knowledge: Creation, transfer and utilization. Sage:London. 2001.

VOTORANTIN. www.votorantim.com.br. Accessed 28 May 2006.

WERNERFELT, B. A Resource-Based View of the Firm. Strategic Management Journal. 5 (1984), 171-180. 1984.

YIN, R.K. Case study research: Design and Methods. Sage:Thousand Oaks, California. 1994.

\section{Sobre os autores:}

\section{Belmiro do Nascimento João}

Professor da Pontifícia Universidade Católica de São Paulo e da Universidade Católica de Santos, Mestrado em Gestão de Negócios

bjoao@pucsp.br

\section{Matheus Iwao Oshikiri}

mestrando em Administração pela Pontifícia Universidade Católica de São Paulo

\section{Aldo Brunhara}

Mestrando em Administração pela Pontifícia Universidade Católica de São Paulo 